\title{
論文
}

\section{A Simulation System for Viscoelastic Properties of Polydisperse Polymer Melts}

\author{
Shigeru $\mathrm{YAO}^{* 1}$, Tatsuya SHOJI ${ }^{* 1}$, Eiichi $\mathrm{KAMEI}^{* 1}$ and Masaoki TAKAHASHI ${ }^{* 2}$ \\ ${ }^{* 1}$ Hirakata Laboratory, Corporate Research $\mathcal{E}$ Development, Ube Industries, Ltd., \\ 3-10, Nakamiya Kita-machi, Hirakata 573 \\ *2Department of Polymer Chemistry, Kyoto University, Kyoto 606
}

\begin{abstract}
A simulation system is developed for evaluating viscoelastic properties of polymer melts with arbitrary polydispersity in molecular weight, starting from the known chemical structure of the polymers. The critical molecular weight for entanglement and molecular weight dependence of zero shear viscosity are evaluated based on theories of van Krevelen and Berry-Fox by optimizing parameters associated with chain flexibility, chain length and effective molar weight per repeating unit. In the evaluation of viscoelastic properties of polymer melts, simple and reasonable shape of relaxation spectrum is assumed for polydisperse systems. Using molecular parameters evaluated above, frequency dependence of viscoleastic functions is calculated from the relaxation spectrum. This method is shown to be superior to the usual way of calculation of viscoelasticity based on blending rules: The time needed for the calculation is very short and does not depend on the polydispersity in molecular weight. Combination of the present method with an appropriate constitutive equation gives a system for evaluating nonlinear viscoelastic properties of polydisperse polymers.
\end{abstract}

Key words: Simulation / Viscoelastic properties / Polymer melt / Polydispersity

\section{多分散系溶融高分子の粘弾性推算システム}

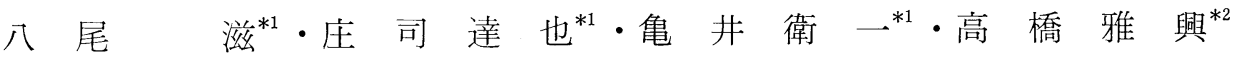 \\ （原稿受理：平成 5 年 1 月 22 日）
}

1. 緒

言

最近, CAE (Computer Aided Engineering) を適用して，か なりの精度で溶融高分子の金型内流動などをシミュレートできる ようになり，金型設計及び製品開発の効率化に CAE が大きく貢 献している. しかし, 精度の高いシミュレーションを行うには, 溶融高分子の粘弾性的性質や熱的性質をデータとして入力する必 要がある. 熱的性質は高分子種に固有のものである. しかし, 粘 弾性的性質は分子量, 分子量分布, 枝分かれなどに大きく依存し, 現状では試料毎に実測しなければならない，従って，粘弾性的性 質を精度良く推算できれば，この方面の研究を大幅に効率化する ことが可能となる.さらに一歩進んで, 高分子の化学構造から推 算することが可能になれば, 新規材料の開発・製品化への効率化 が図れることになる。

単分散試料の粘弾性的性質に関する研究は, 粘弾性関数の分子

*1 宇部興産(株)研究開発本部枚方研究所

T573 枚方市中宮北町 $3-10$

*2 京都大学工学部高分子化学教室 $\overline{\mathbf{T}} 606$ 京都市左京区吉田本町
量依存性を初めとして数多く存在する. 従って, 単分散試料に限 定すれば, 粘度のせん断速度依存性などを推算することは比較的 容易である. 一方, 多分散試料に関しては, その粘弾性的性質を 説明するために多くのブレンド則が提案されているが，分子量の 異なった高分子間の相互作用を表す項をどら見積もるかが困難な こと，また分子量分布の広い系については計算量が膨大になるこ となどから，推算は非常に困難である.

今回我々は従来とは全く異なった発想から, 多分散試料の粘弾 性的性質を, 高分子の化学構造から容易にかつ正確に推算するシ ステムを構築したので報告する。

2. 臨界分子量, ゼロせん断粘度, コンプライアンス の推算

$2 \cdot 1$ 推算手法の概略

高分子の化学構造から多分散試料の粘弾性的性質 (ここでは主 に貯蔵弾性率 $G^{\prime}$ と損失弾性率 $G^{\prime \prime}$ ) を推算するには, まず単分散 試料について推算が出来なくてはならない. 単分散試料の粘弾性 的性質の推算は, 溶融粘度の臨界分子量 $\left(M_{\mathrm{c}}\right)$ もしくは絡み合い 
点間分子量 $\left(M_{\mathrm{e}}\right)$, 及びゼロせん断粘度 $\left(\eta_{0}\right)$ の分子量依存性が化 学構造から推算できることが前提となる.

前者の $M_{\mathrm{c}}$ に関しては, van Krevelen の式占を初めとして, 加成性に基づいた推算式が種々提案されている. 本研究では, 次 節 $2 \cdot 2$ で示すよ 5 に, van Krevelen の推算式を検討し, 各基本 原子団毎に割り当てられたパラメータを最適化することにより， 溶融粘度の臨界分子量 $M_{\mathrm{c}}$ をかなりの精度で推算できることを見 いだした。

後者, 即ち $\eta_{0}$ の分子量依存性に関する代表的な推算式には, Berry-Fox の 式2) van Krevelenの式とが存在する. 彼らの式 を提示された通りに用いると, 実測值とかなりかけ離れた計算值 しか得られない. 本研究では, $2 \cdot 3$ 節に示すように, パラメータ の最適化で推算精度を飛躍的に高めた。

これらの結果を用いると, 次式 (1) 及び (2) 飞従って種々の 分子量の単分散試料の最長緩和時間 $\tau_{\mathrm{d}}$ と擬平衡弾性率 $G_{\mathrm{N}}{ }^{0}$ を求 めることが出来る.

$$
\begin{aligned}
& \tau_{\mathrm{d}} \sim \tau_{\mathrm{w}}=\eta_{0} \cdot J_{\mathrm{e}}^{0} \\
& G_{\mathrm{N}}^{0}=\frac{\rho R T}{M_{\mathrm{e}}}
\end{aligned}
$$

ここで， $\tau_{\mathrm{w}}$ は重量平均緩和時間であり， $J_{\mathrm{e}}{ }^{0}$ は定常状態コンプ ライアンスである. 絡及合い点間分子量 $M_{\mathrm{e}}$ は, $M_{\mathrm{e}}=M_{\mathrm{c}} / 2$ と した。また， $J_{\mathrm{e}}^{0}$ は次式で評価した。

$$
\begin{array}{ll}
J_{\mathrm{e}}^{0}=\frac{0.40 M}{\rho R T} & \left(M<M_{\mathrm{c}}{ }^{\prime}\right) \\
J_{\mathrm{e}}^{0}=\frac{1.798 M_{\mathrm{e}}}{\rho R T} & \left(M>M_{\mathrm{c}}{ }^{\prime}\right)
\end{array}
$$

ここで， $M_{\mathrm{c}}{ }^{\prime}$ は $J_{\mathrm{e}}{ }^{0}$ に対する臨界分子量である。式 (3-a) は修 正 Rouse 理論に，また式 (3-b) は Graessley の理論に基つい ている ${ }^{3)}$.ちなみに土井-Edwards 理諭では, 係数 1.798 が 1.5 となる゙政。

その他, ガラス転移温度や溶融状態での密度などの物性值につ いても, van Krevelen によって導き出された式及びパラメータ1) を修正することによって，化学構造から推算した。

以上のようにして, 高分子の化学構造から単分散試料の粘弾性

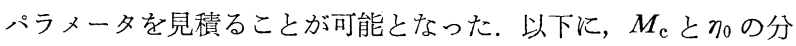
子量依存性の推算の詳細を述べる。

\section{$2 \cdot 2$ 溶融粘度の臨界分子量 $\left(\boldsymbol{M}_{\mathrm{c}}\right)$ の推算}

高分子の化学構造から溶融粘度の臨界分子量を導き出す式とし て, van Kreveklen の式を用いた。 van Kreveklenに従えば, 式 （4）で定義される非摂動関数 $K_{\theta}$ と臨界分子量 $M_{\mathrm{c}}$ は, 式 (5) で表されるような関係を持つ。

$$
\begin{aligned}
& K_{\theta}=\frac{[\eta]_{\theta}}{M_{\mathrm{v}}} \\
& K_{\theta} \cdot M_{\mathrm{c}}^{0.5}=13
\end{aligned}
$$

ここで, $[n] \theta$ は $\theta$ 状態に拈ける固有粘度, $M_{\mathrm{v}}$ は粘度平均分子量 である. さらに, 非摂動関数 $K_{\theta}$ は分子鎖の剛直さと関連する分 子硬化関数 $K$ と分子量 $M$ で表される.

$$
K_{\theta}=\left(\frac{K}{M}\right)^{2}
$$

ここで用いられた分子硬化関数 $K$ は, 各基本構造単位に固有の值 である硬化関数 $K_{\mathrm{i}}$ と主鎖の原子数 $Z_{\mathrm{i}}$ を用いて, 次式で与えら
れる。

$$
K=\Sigma K_{\mathrm{i}}+4.2 \Sigma Z_{\mathrm{i}}
$$

以上のよ5にして, 式 (4)〜 (7) を用いて, 高分子の化学構造 から溶融粘度の臨界分子量を求めることが可能となる。ただし， van Krevelen が各々の基本構造単位に与えた固有值をとのまま 用いると， $M_{\mathrm{c}}$ の計算值が文献值とあまり合わなくなる。従って, 本研究では種々の高分子の臨界分子量の文献值を用いパラメータ フィティングすることにより, 各基本構造単位の $K_{\mathrm{1}}$ 及び $Z_{1}$ の 最適値を求めることによって推算精度を上げるようにした。 この 場合， $Z_{\mathrm{i}}$ は有效鎖長となる。

\section{$2 \cdot 3$ ゼロせん断粘度（ $\left.\boldsymbol{\eta}_{0}\right)$ の分子量依存性の推算}

高分子のゼロせん断粘度の分子量依存性に関しては Berry-Fox の理論があり, 本研究ではこの理論の適用を試みた。

彼らによると高分子の粘度は次式のように，鎖の形態による項 $F(X)$ と摩擦による項 $\zeta(\rho)$ との積によって定義することができ る.

$$
\eta_{0}=F(X) \cdot \zeta(\rho)
$$

ここで, $F(X)$ は次式で与えられる.

$$
F(X)=\left(\frac{N_{\mathrm{A}}}{6}\right) \cdot X_{\mathrm{c}} \cdot\left(\frac{X}{X_{\mathrm{c}}}\right)^{\mathrm{a}}
$$

$N_{\mathrm{A}}$ はアボガドロ数である．また， $a$ はゼロせん断粘度の分子鎖 長依存性に関する指数であり, 分子量が小さいときは 1 で臨界值 を過ぎて大きくなると，批拈よそ3.4となる， $X_{\mathrm{c}}$ はその臨界值を 表すパラメータであり，式（10）で定義される.

$$
X_{\mathrm{c}}=Z_{\mathrm{c}}\left(\frac{\left\langle s^{2}\right\rangle_{0}}{M_{\mathrm{c}} \cdot v}\right)
$$

ここで, $Z_{\mathrm{c}}$ は臨界鎖長, $\left\langle s^{2}\right\rangle_{0}$ は慣性半径の 2 乗平均, $M_{\mathrm{c}}$ は臨 界分子量, $v$ は比容である. $X_{\mathrm{c}}$ の值は Berry らによると高分 子鎖の形状によらずほぽ一定值となり，打打よそ $\log \left(X_{\mathrm{c}}\right)=$ 14.40 となる．Xは式 (10)を任意の鎖長及び鎖形状に刘して定義 しな扎したので，次式で定義される．

$$
X=g \cdot Z\left(\frac{\left\langle s^{2}\right\rangle_{0}}{M \cdot v}\right)
$$

ここで, $Z$ は鎖長, $M$ は分子量, また $g$ は分岐がある場合の慣性 半径と無い場合の慣性半径の比であり, 近似的に式 (12) で与兄 ることができる。

$$
g=\frac{6 p}{(p+1)(p+2)}
$$

ここで, $p$ は繰り返し単位当たりの分岐数である（分岐が無い場 合は $p=1$ ).

摩擦項 $\zeta(\rho)$ もまた次式のように，3つの項の積であらわさ れる。

$$
\zeta(\rho)=\zeta_{00} \cdot \exp \left(\frac{W}{T}\right) \cdot \exp \left(\frac{B}{f_{\mathrm{g}}+\alpha_{1}\left(T-T_{\mathrm{g}}\right)}\right)
$$

ここで, $\zeta_{00}$ は温度無限大での摩擦係数であり, $\log \zeta_{00}=-10.6$ で与えられる定数である。 また，Wは温度を低下した場合に増加 する摩擦係数に対する純粋に温度のみの寄与による増加量を表し， 多くのばあい $W /(2.303 \cdot T) \sim 1$ である. ただし，この量は分子 の剛直さに依存して增減する. 第 3 項は, 温度によって変化する 自由体積が摩擦係数に与学る影響を表す。ここで，Bはセグメン 
卜運動に必要な臨界体積を与えるパラメータであり， $f_{\mathrm{g}}$ はガラ ス転移温度に抢ける自由体積分率， $\alpha_{1}$ は溶融状態に打ける熱膨 張率である.

式 (8) から式 (13) を組み合わせ，またそれぞれのパラメータ に近似值を代入することにより，ゼロせん断粘度は次式によって 与えられる。

$$
\log \left(\eta_{0}\right)=a \cdot \log \left(g \cdot \frac{Z}{m_{\mathrm{u}}}\right)-1.1(a-1)-4.1+\frac{1000}{57.5+T-T_{\mathrm{g}}}
$$

ここで， $m_{\mathrm{u}}$ は単位有效鎖長当たりのモル重量である。また，鎤 長 $Z$ は次式によって定義される有效鎖長である.

$$
Z=\frac{z_{\mathrm{u}} M}{m_{\mathrm{u}}}
$$

ここで, $z_{\mathrm{u}}$ は繰り返し単位当たりの有効鎖長である.

式（14）及び式（15）で問題となるのは，モル重量 $m_{\mathrm{u}}$ の評缏 である. Berry らは，Zを基本構造単位の数として考宇た場合， $m_{\mathrm{u}}$ は繰り返し単位当たりのモル重量で与えることができるとし

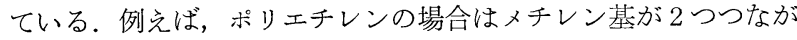
って繰り返し単位を形成しているため， $z_{\mathrm{u}}$ の值は 2 となり，その 時の有效モル重量は約28となる。彼らの考㝋に従って, 式 (14) 及び式（15）を用い種々の高分子の溶融ゼロせん断粘度の推算を 行った。 Fig. 1 に推算值と実測值の比較を示す。図から明らか なように，ポリエチレンなど数種類の高分子を除いて，推算值は 実測值と大きくずれる。すなわち，Berry らの述べたような手法 で各置換基のパラメータを決定することには無理があることが分 かる.

推算值と実測值のずれは，有効モル重量を繰り返し単位のモル 分子量として，計算にそのまま用いたために生じた結果であると 考兄られる，例えば，側鎖が大さいものはとれだけ鎖の移動に大 きな抵抗を受けると考光る方が妥当性がある. 従って, そのよ5

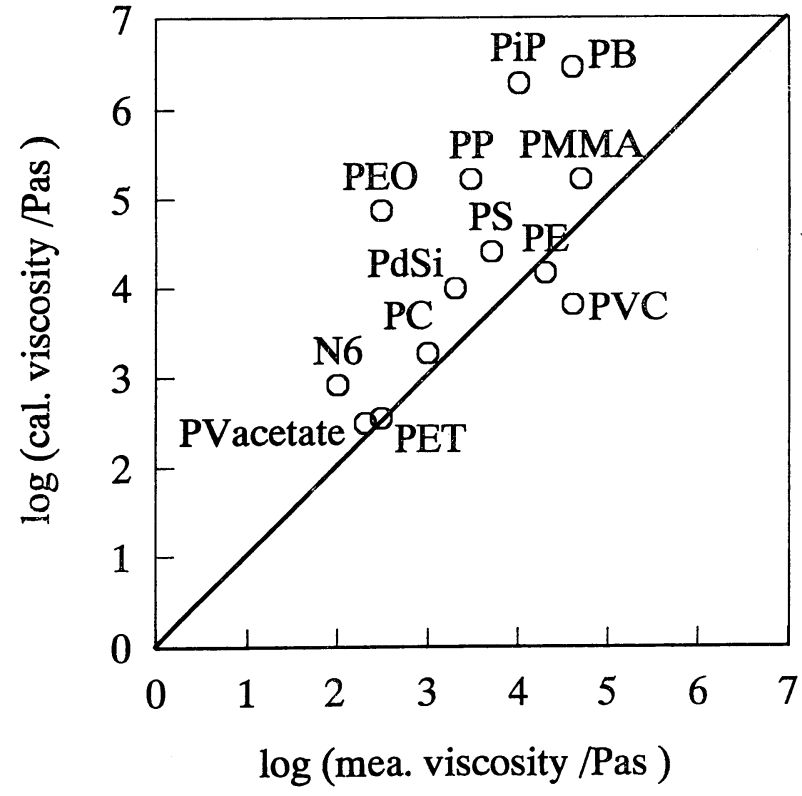

Fig. 1 Comparison between measured zero-shear viscosities of various polymers and predicted ones by Berry-Fox theory.
な系に招いては，有効モル重量はモル分子量よりも大きく見積ら ねばならないであろう。

Fig. 1 に示した全ての高分子に対する粘度の推算值ができる だけ実測值に近くなるよう $m_{\mathrm{u}}$ を最適化した. Table I に，ビニル 系の高分子について, 繰り返し単位当たりのモル分子量と導き出 された有效モル重量とを対比して示す。表からも明らかなように,

Table I. The molar weight and the effective weight of

\begin{tabular}{|c|c|c|}
\hline structure & molar weight & effective weight \\
\hline$-\mathrm{CH}_{2}-$ & 14.03 & 14.77 \\
\hline $\begin{array}{c}-\mathrm{CH}- \\
\stackrel{\mathrm{C}}{\mathrm{CH}} \mathrm{H}_{3}\end{array}$ & 28.06 & 69.41 \\
\hline$\underset{\mid}{-\mathrm{CH}-}$ & 90.13 & 128.90 \\
\hline $\begin{array}{c}-\mathrm{CH}- \\
\mathrm{Cl}\end{array}$ & 48.52 & 38.45 \\
\hline $\begin{array}{l}\mathrm{CH}_{3} \\
-\mathrm{C}- \\
\mathrm{C}=\mathrm{O} \\
\mathrm{OCH} \mathrm{CH}_{3}\end{array}$ & 86.10 & 159.40 \\
\hline $\begin{array}{c}\mathrm{CH}_{3} \\
-\mathrm{C}- \\
\stackrel{\mathrm{O}}{\mathrm{C}}=\mathrm{O} \\
\mathrm{CH}_{3}\end{array}$ & 86.10 & 87.21 \\
\hline$-\mathrm{CH}=\mathrm{CH}-$ & 26.04 & 78.66 \\
\hline $\begin{aligned}-\mathrm{CH}= & \mathrm{l}- \\
& \stackrel{\mathrm{CH}}{\mathrm{CH}_{3}}\end{aligned}$ & 40.08 & 106.74 \\
\hline
\end{tabular}
vinyl polymers with various chemical structures.

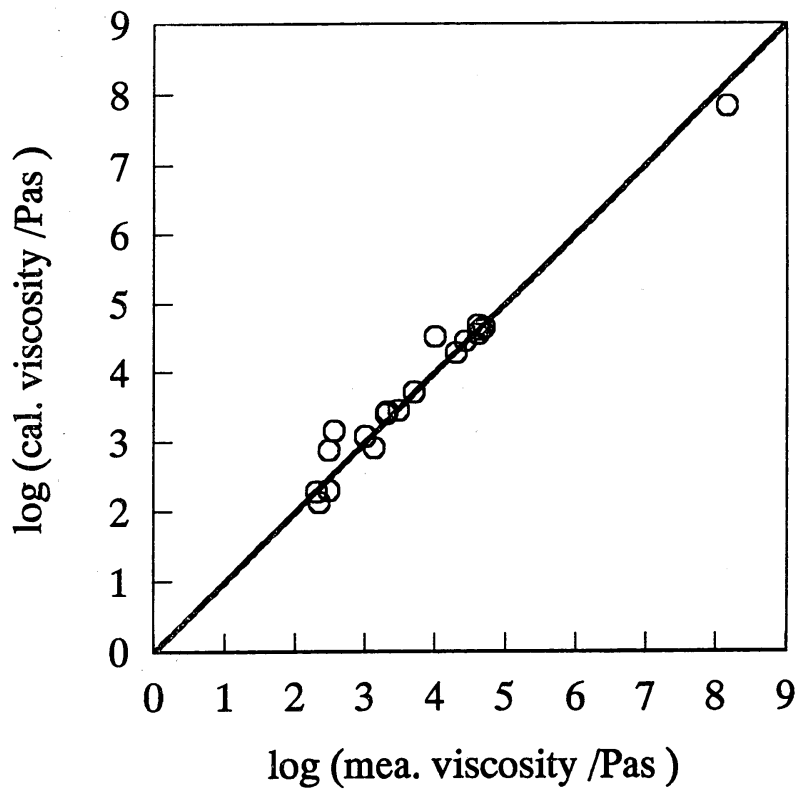

Fig. 2 Comparison between measured zero-shear viscosities of various polymers and predicted ones by modified Berry-Fox theory. 
側鎖の大きな繰り返し単位は，一般にモル分子量よりも大きな有 効分子量を持つことが分かる，乙かし例外もあり，側鎖のたわみ 易さや極性など複雑な要因が有効分子量に影響しているように見 える．また，主鎖に 2 重結合のあるものは有効分子量が非常に高 くなっているが，この原因はよく分からない。

式(14)及び式(15)飞従了と, ゼロせん断粘度の分子量依存性は 臨界分子量前後で不連続となる. この補正も加えた後, 種々の高 分子について推算を行った結果と実測值との関係を, Fig. 2 に 示す。図から明らかなように，上に述べたような修正と補正を加 えることによって, Berry-Fox の式を用いて, 高分子の化学構造 から溶融高分子のゼ口せん断粘度の分子量依存性を推算すること が出来ることが分かる.

\section{3. 混合則を用いた粘弾性関数の推算}

単分散試料の粘弾性関数を与える式として, 次の土井-Edwards の式を用いた ${ }^{4}$.

$$
\begin{aligned}
& G^{\prime}(\omega)=G_{\mathrm{N}}^{0} \sum_{\mathrm{p}: \text { odd }} \frac{8}{\pi^{2} p^{2}} \frac{\omega^{2} \tau_{\mathrm{p}}^{2}}{1+\omega^{2} \tau_{\mathrm{p}}^{2}} \\
& G^{\prime \prime}(\omega)=G_{\mathrm{N}}^{0} \sum_{\mathrm{p}: \text { odd }} \frac{8}{\pi^{2} p^{2}} \frac{\omega \tau_{\mathrm{p}}}{1+\omega^{2} \tau_{\mathrm{p}}{ }^{2}}
\end{aligned}
$$

ここで，緩和時間 $\tau_{\mathrm{p}}$ は，次式で与えられる.

$$
\begin{aligned}
& \tau_{\mathrm{p}}=\frac{\tau_{1}}{p^{2}} \\
& \tau_{1}=\frac{15 \eta_{0} M_{\mathrm{e}}}{\pi^{2} \rho R T}
\end{aligned}
$$

また，ブレンド則として $\mathrm{BMEO}$ 式占を次式のように拡張して 用い, 多分散試料の粘弾性関数の試算を行った.

$$
G^{*}(\omega)=\sum_{\mathrm{i}, \mathrm{j}}\left\{\phi_{\mathrm{i}}{ }^{2} G_{\mathrm{i}}{ }^{*}\left(\omega \lambda_{\mathrm{i}}\right)+2 \phi_{\mathrm{i}} \phi_{\mathrm{j}} G_{\mathrm{ij}}{ }^{*}\left(\omega \lambda_{\mathrm{ij}}\right)+\phi_{\mathrm{j}}{ }^{2} G_{\mathrm{j}}{ }^{*}\left(\omega \lambda_{\mathrm{j}}\right)\right\}
$$

ここで, $i, j$ は単分散とみなした $i$ 成分と $j$ 成分を表し，和は $i$ とjの全ての組文合わせについて行万ものとする。 $\phi_{\mathrm{i}}$ は $i$ 成分の 体積分率， $\lambda_{\mathrm{i}}$ は全体の重量平均分子量と $i$ 成分の分子量の比の 1.4 乗, $\lambda_{\mathrm{j} j}$ は $\lambda_{\mathrm{i}}$ と $\lambda_{\mathrm{j}}$ の積の 0.5 乗である. 簡単のため $G_{\mathrm{ij}}{ }^{*}$ は, $G_{\mathrm{i}}{ }^{*}$ と $G_{\mathrm{j}}{ }^{*}$ の数平均で与えた.

升田らのポリスチレンのデータを用い6)，式(16)〜(18) を適用 して導いた推算值と実測值とを Fig. 3 亿比較する. 図中記号は 升田らのデータから代表的な值を取り出したるのであり, 実測值 の概略を与えるものである。また，実線は上式を用いて推算され た $G^{\prime}$ 及び $G^{\prime \prime}$ の值である. $i, j$ などの成分への分割にあたっ ては, 分子量分布曲線が Zimm-Schultz 分布であるとして, そ れを単分散とみなせるまで十分細かく分割した，以上の結果，比 較的分子量分布の狭い系についても非常に長い計算時間を必要と すること $\left(M_{\mathrm{w}} / M_{\mathrm{n}}=1.57\right.$ の系で約 5 時間 $)$, 及び推算值と実測值 の一致がよくないことが分かった.

従って, 土井-Edwards 理論とブレンド則を用いて, 多分散試 料の粘弾性関数を推算することは非常に困難であり, かつ結果も 思わしくないと判断された。

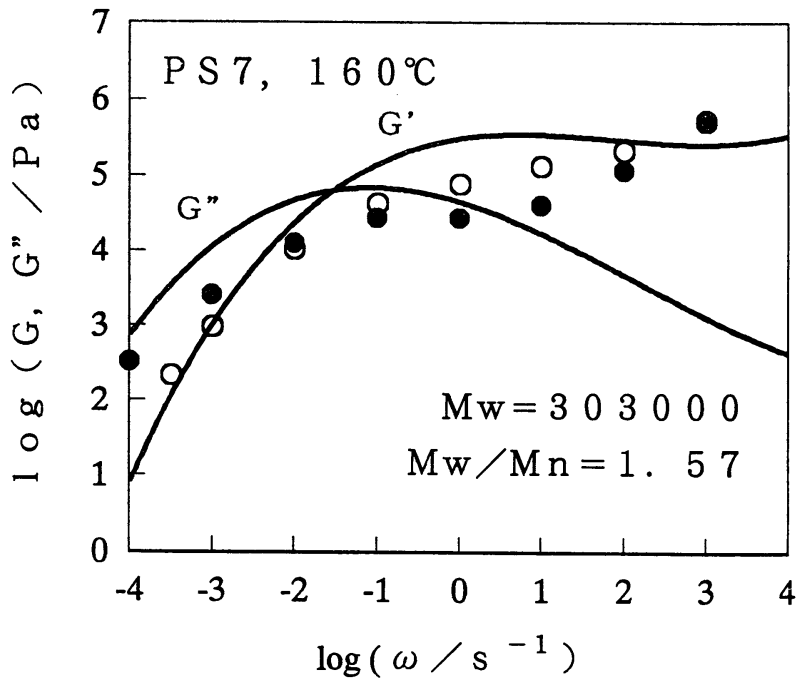

Fig. 3 Comparison between measured (circles) ${ }^{6}$ ) and predicted (curves) storage modulus $G^{\prime}$ and loss modulus $G^{\prime \prime}$ of polystyrene PS7 at $160^{\circ} \mathrm{C}$. The predicted curves are obtained by modification of BMEO theory combined with the Doi-Edwards theory.

\section{4. 緩和スペクトルに基づく粘弾性関数の推算}

粘弾性関数を求める目的の一つに, 緩和スペクトルの算出があ る. 逆に, 緩和スペクトルを推算することが出来れば, これら粘 弾性関数は数式的に導き出すことができる. そこで, 緩和スペク トルの推算を試みた.

単分散試料の緩和スペクトルは, Fig. 4 に示すように, モデル 的に楔型部位とBox 型部位に分割して考えることができる．Box 型部位が終了する最長緩和時間 $\tau_{\mathrm{MM}}$ は, 重量平均緩和時間 $\tau_{\mathrm{w}}$ の 程度であり, 楔型部位と Box 型部位との境界を与える時間 $\left(\tau_{\mathrm{tr}}\right)$ は, 式(19)で表される Graessley の式7)によって与えることがで さる。

$$
\frac{\tau_{\mathrm{w}}}{\tau_{\mathrm{tr}}}=0.3\left(\frac{M}{M_{\mathrm{e}}}\right)^{3.5}
$$

また, Box の高さ $\left(H_{\mathrm{p}}\right)$ は, ゼ口せん断粘度と緩和スペクトル の間の関係式から求められ，次式で表される。

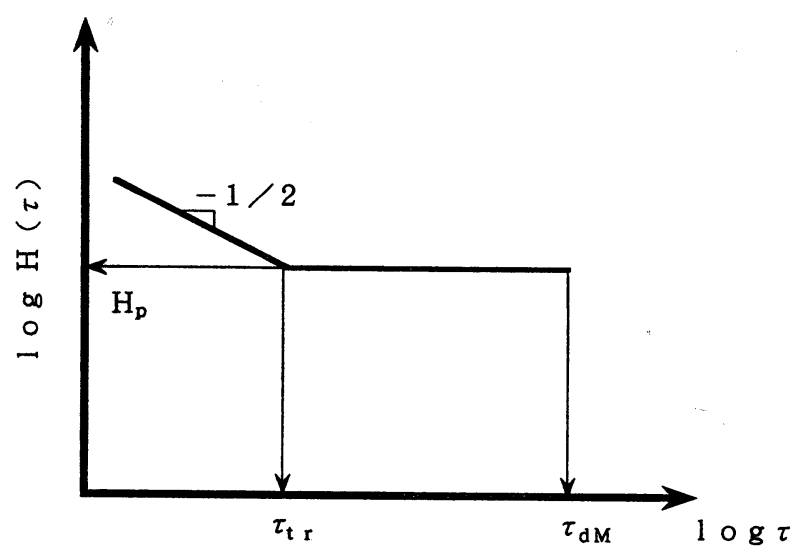

Fig. 4 Schematic representation of the relaxation spectrum of monodisperse system. 


$$
H_{\mathrm{p}}=\frac{\eta_{0}}{2 \tau_{\mathrm{tr}}{ }^{0.5}+\tau_{\mathrm{w}}-\tau_{\mathrm{tr}}}
$$

これらの関係式を用いることにより，模式化された単分散試料の 緩和スペクトルを比較的容易に求められる.

次に，重量平均分子量 $M_{\mathrm{w}}$ が同じ場合の単分散試料と多分散 試料の緩和スペクトルの比較を行った。 まず， $\tau_{\mathrm{tr}}$ 及びそれ以下 の時間域でのスペクトル形状は同一である。また，多分散試料の 重量平均緩和時間は長時間側にシフトするが，この原因は定常状 態コンプライアンスの増加に起因している. この值は式(21)によ って与えられる

$$
J_{\mathrm{eB}}^{0}=J_{\mathrm{eM}^{0}}\left(\frac{M_{\mathrm{z}}}{M_{\mathrm{w}}}\right)^{\mathrm{b}}
$$

ここで, $J_{\mathrm{eB}}{ }^{0}$ は多分散系の定常状態コンプライアンス, $J_{\mathrm{eM}}{ }^{0}$ は 単分散系の定常状態コンプライアンス， $M_{z}$ は多分散系の $z$ 平均 分子量，また $b$ は定数であり，2.0〜3.5の值をとる.

さらに, 多くの実験から多分散試料の緩和スペクトルは, 最長 緩和時間付近で急激に減少するのではなく, 緩やかに減少するこ とが知られている，とこで，今回これらのスペクトルを推算する に亦たっては, 単分散と対応する最長緩和時間以降適当な時間範 团に扔いて，両対数で傾きー 1 の直線に従って，ある緩和時間て $\mathrm{e}$ までスペクトルが減少するものとした (Fig. 5 参照)

また, 雷量平均分子量が同じ場合にはゼロせん断粘度が同じに なることから，次式で示されるように単分散試料の緩和スペクト ル $H(\tau)$ と, 多分散試料の緩和スペクトル $H_{\mathrm{B}}(\tilde{\imath})$ の積分が同じ になる。

$$
\int^{\tau_{\mathrm{dm}}} H(\tau) \tau d \ln \tau=\int^{\tau_{\mathrm{e}}} H(\tau) \tau d \ln \tau
$$

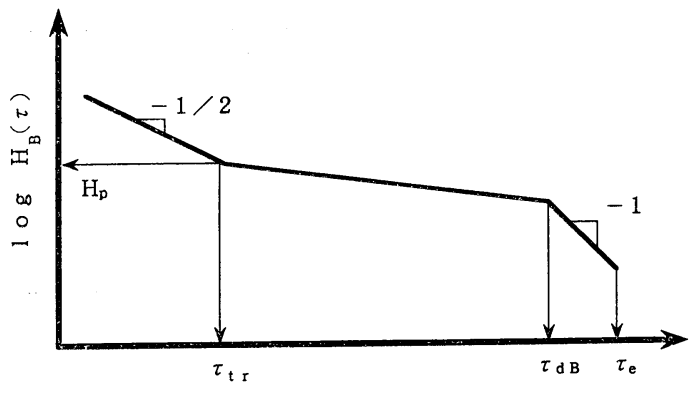

Fig. 5 Schematic representation of the relaxation spectrum of polydisperse system.

以上により，多分散試料の緩和スペクトルは Fig. 5 に示すよ うに, 両対数グラフ上で一定の傾きを持つ 3 本の直線で近似でき る。この様にして緩和スペクトルが与えられると， $G^{\prime}$ 及び $G^{\prime \prime}$ は 次式によって求めることができる.

$$
\begin{aligned}
& G^{\prime}(\omega)=\int_{-\infty}^{\infty}\left[H(\tau) \frac{\omega^{2} \tau^{2}}{1+\omega^{2} \tau^{2}}\right] d \ln \tau \\
& G^{\prime \prime}(\omega)=\int_{-\infty}^{\infty}\left[H(\tau) \frac{\omega \tau}{1+\omega^{2} \tau^{2}}\right] d \ln \tau
\end{aligned}
$$

すなわち, 式(19)〜(23)を用いることにより, 多分散試料の緩 和スペクトル及び $G^{\prime}, G^{\prime \prime}$ を推算することができる.

\section{5. 実験結果との比較}

以上の考えに従って算出された多分散試料の $G^{\prime}$ と $G^{\prime \prime}$ と実測

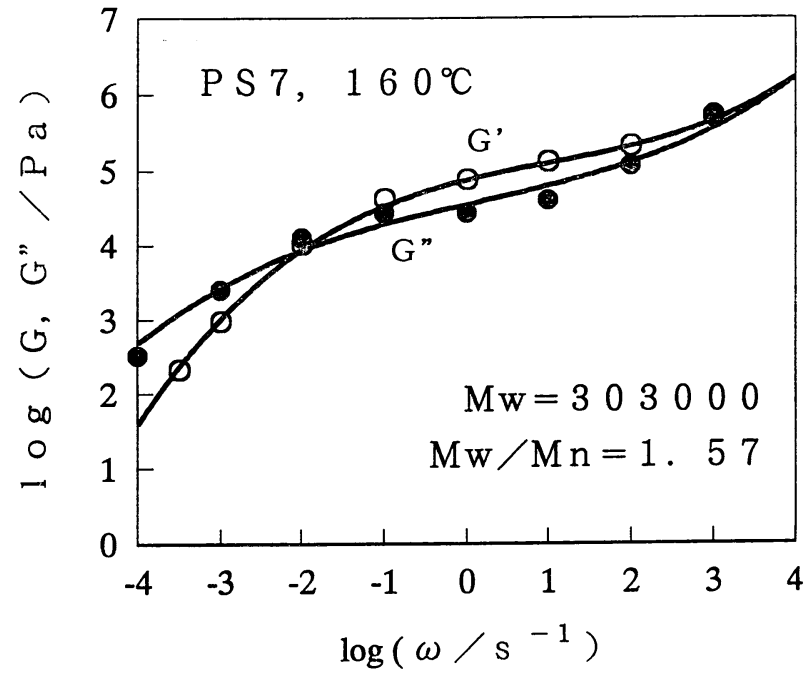

Fig. 6 Comparison between measured (circles) ${ }^{6}$ ) and predicted (curves) storage modulus $G^{\prime}$ and loss modulus $G^{\prime \prime}$ of polystyrene PS7 at $160^{\circ} \mathrm{C}$. The predicted curves are based on the present theory (see text).

值との比較を, 種々の分散度を持つ高分子系に対して行った。

Fig. 6 は，さきに示した升田らの実測值との比較を示したもの である。図から明らかなように，推算值と実測值は広い周波数範 用で良く一致している。

また, Fig. 7 は Minoshimaらによるポリプロピレンのせん断 粘度クのせん断速度字依存性を調べたデータ ${ }^{9)}$ と，推算結果とを 比較したものである。図中記号は Fig. 6 と同じく実測值の代表 的な点を示した. 推算值としては, 複素粘度の絶対值 $\left|\eta^{*}\right|$ の周波 数 $\omega$ 依存性曲線を用いた。 よく知られているょ5に, Cox-Merz の経験則が成立するときは， $\dot{\gamma}=\omega$ で $\eta=\left|\eta^{*}\right|$ の関係がある。 こ れらの結果から, $M_{\mathrm{w}} / M_{\mathrm{n}}$ が $4.7 \sim 9.0$ と比較的広い分子量分布 を持つ場合でも，この推算方法が広いひずみ速度範囲で適用でき ることが分かる。

分子量分布がさらに広い系に対する本推算方法の適用性を調べ たのが，Fig. 8 である。実測值としては，LaunによるLDPE $\left(M_{\mathrm{w}} / M_{\mathrm{n}}=22\right)$ の結果を用いた ${ }^{10)}$. 図から明らかなように，分 子量分布が非常に広い系汶対しても，本推算方法は非常に有効で

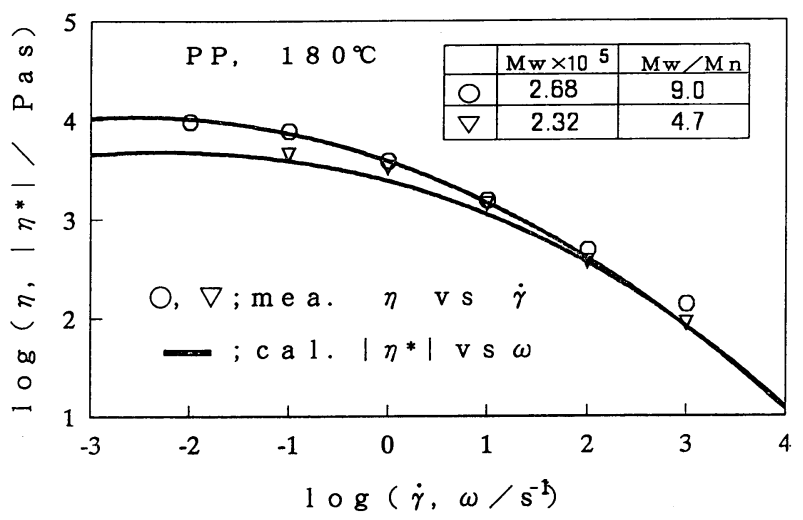

Fig. 7 Measured shear rate dependence of viscosity $\eta^{9)}$ and predicted frequency dependence of dynamic viscosity $\left|\eta^{*}\right|$ for polypropylene at $180^{\circ} \mathrm{C}$. 


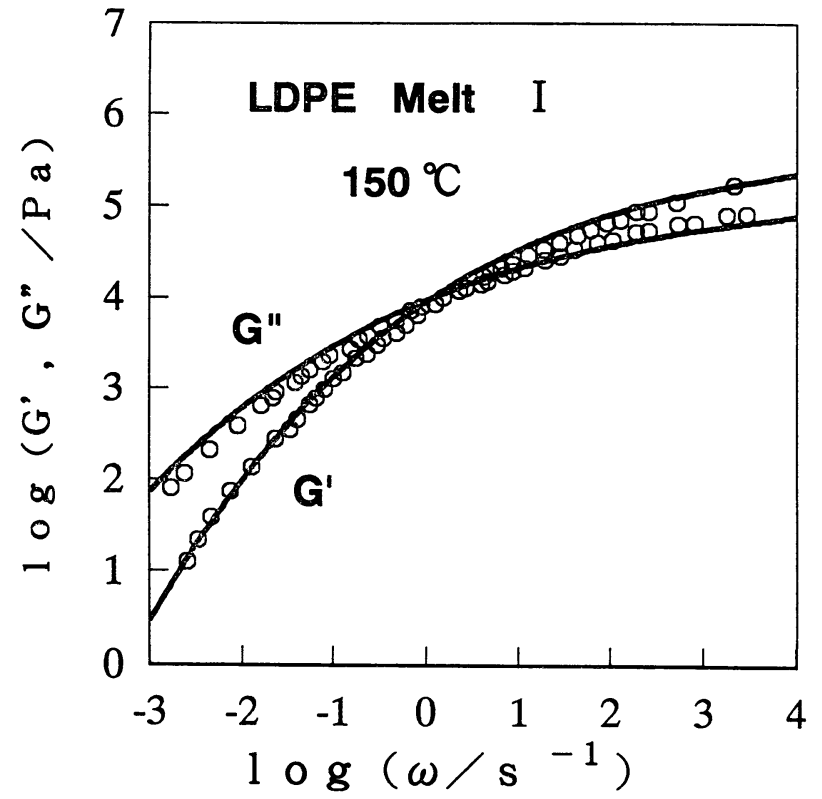

Fig. 8 Storage modulus $G^{\prime}$ and loss modulus $G^{\prime \prime}$ of LDPE Melt I at $150^{\circ} \mathrm{C}$. The circles show experimental data ${ }^{10)}$, and the solid curves the prediction of the present theory.

あることが分かる.

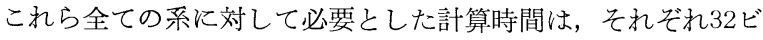
ットのパソコンで約 5 分である。すなわち，本推算方法はエキス パートシステムとして実用に耐えるものである.

\section{6. 定常流粘度と法線応力}

このようにして求めた緩和スペクトルを種々の構成方程式に適 用することにより，他の粘弾性的性質を推算することができる。

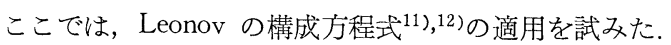

Leonov などの微分形構成方程式を用いるためには，まず緩和 スペクトルを線スペクトルに分割しなくてはならない。ここでは 高橋らの方法 ${ }^{13)}$ に従い，次式によって機械的に分割した。

$$
\begin{aligned}
& \frac{\tau_{\mathrm{n}}}{\tau_{\mathrm{n}+1}}=3.6 \\
& G_{\mathrm{n}}=1.28 H\left(\tau_{\mathrm{n}}\right)
\end{aligned}
$$

この $G_{\mathrm{n}}$ と盀を用いて，定常流下のせん断応力 $\sigma(\dot{\gamma})$, 及び第一 法線応力差 $N_{1}(\dot{\gamma})$ は, Leonov モデルではそれぞれ式 (25), (26) で与兄らる.

$$
\begin{aligned}
& \sigma_{12}=2 \dot{\gamma} \sum_{\mathrm{n}}\left[\frac{G_{\mathrm{n}} \tau_{\mathrm{n}}}{X_{\mathrm{n}}+1}\right] \\
& N_{1}=\sqrt{2} \sum_{\mathrm{n}}\left[\frac{G_{\mathrm{n}}\left(X_{\mathrm{n}}-1\right)}{\left(X_{\mathrm{n}}+1\right)^{0.5}}\right]
\end{aligned}
$$

ここで， $X_{\mathrm{n}}$ は次式で定義される.

$$
X_{\mathrm{n}}=\left(1+4 \dot{\gamma}^{2} \tau_{\mathrm{n}}^{2}\right)^{0.5}
$$

Fig. 9 飞 Fig. 8 と同じ試料について, 粘度クと第一法線応 力係数 $\psi_{1}$ の推算值と実測值を比較する。 ここで， $\phi_{1}$ は次式で 定義される.

$$
\psi_{1}=\frac{N_{1}}{\dot{\gamma}^{2}}
$$

Fig. 9 によれば，推算值は実測值と非常によく一致している.

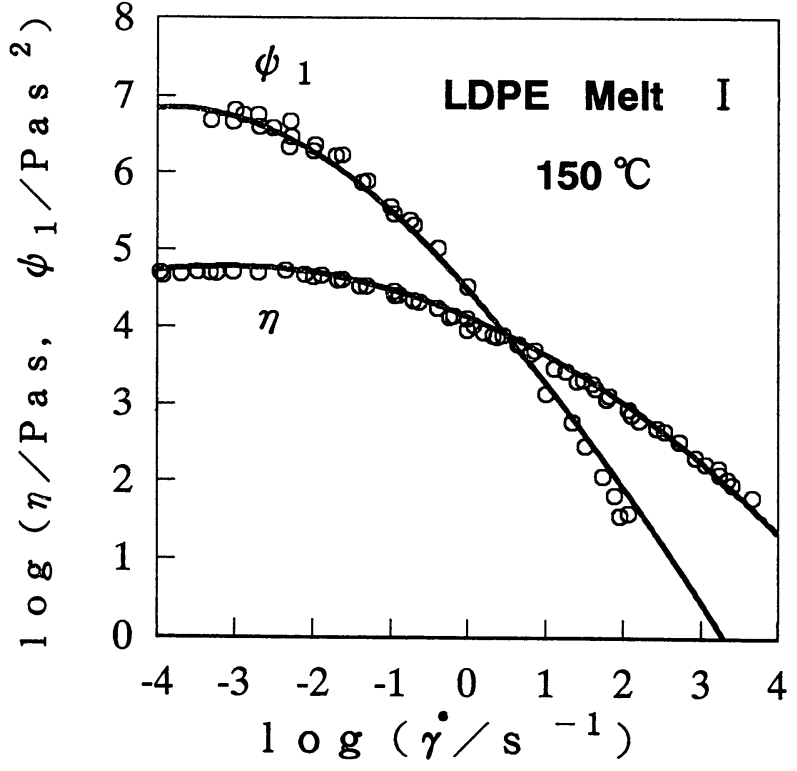

Fig. 9 Shear rate dependence of viscosity $\eta$ and coefficient of first normal stress difference $\psi_{1}$ of LDPE Melt I at $150^{\circ} \mathrm{C}$. The circles show experimental data $^{10)}$ and the solid curves are the prediction of the present theory combined with the Leonov model.

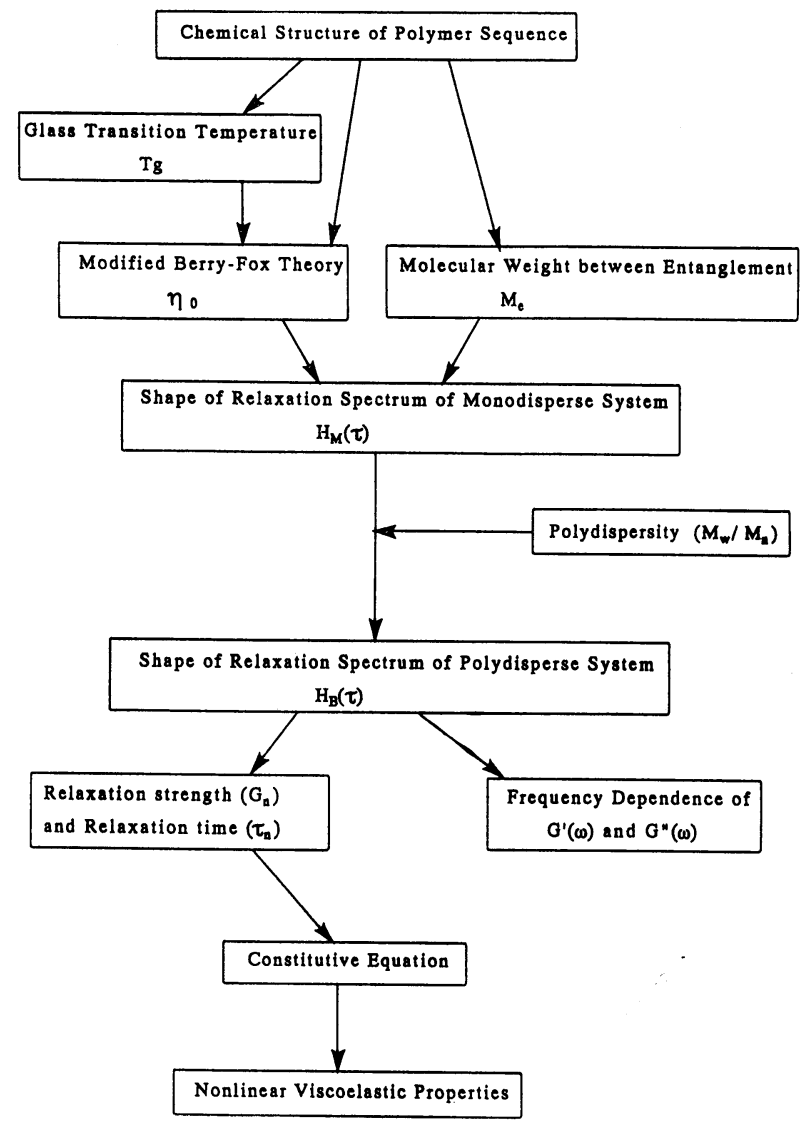

Fig. 10 Algorithm of the present system.

Fig. 9 の推算值を得るのに要した計算時間は先の場合と比較し て非常に短く，この手法が粘弾性的性質の推算に非常に有效であ ることがわかる. 


\section{7. 結論}

絡み合い点間分子量及びゼロせん断粘度の分子量依存性を, 高 分子の化学構造から推算する既存の推算式の適用性を検討した. その結果, 原子団每に与えられている固有値及び式の一部を修正 することによって，適用性が飛躍的に良くなることを見いだした．

また，多分散系の粘弾性的性質を推算する手法として，従来の ブレンド則に替わる緩和スペクトルの形状と，既存の粘弾性の基 本㤩に着目した新たな手法を確立した。 この手法は計算時間が分 散度に依存することなく，また非常に短時間で広い周波数領域の 粘弾性関数を推算することができる。

これらを組み合わせることによって, 高分子の化学構造から任 意の分散度を持つ系の溶融粘弾性関数を推算できるエキスパート システムを構築した。

また，この新たな手法を適当な構成方程式と組み合わせること によって，多分散系溶融高分子の非線形粘弾性を推算するシステ ムを構築することができることが示された．Fig. 10 に本システ ムのアルゴリズムを示す.

\section{文献}

1) van Krevelen DW, "Properties of Polymers", 3rd ed, Elsevier 1990.
2) Berry GC, Fox TG, Adv Polym Sci, 5, 261 (1968).

3) Ferry JD, "Viscoelastic Properties of Polymers", 3rd ed, John Wiley 1980.

4) Doi M, Edwards SF, "The Theory of Polymer Dynamics", Clarenden Press, Oxford 1986.

5) Bogue DC, Masuda T, Einaga T, Onogi S, Polym $J$, 1, 563 (1970).

6) Masuda $\mathrm{T}$, Kitagawa $\mathrm{K}$, Inoue $\mathrm{T}$, Onogi S, Macro. molecules, 3, 116 (1970).

7) Graessley WW, J Chem Phys, 54, 5143 (1971).

8) Kurata M, Osaki K, Einaga Y, Sugie T, J Polym Sci, Polym Phys ed, 12, 849 (1974).

9) Minoshima W, White JL, Sprulell JE, Polym Eng Sci, 20, 1166 (1980).

10) Laun HM, Rheol Acta, 17, 1 (1978).

11) Leonov AI, Rheol Acta, 15, 85 (1976).

12) Leonov AI, Lipkima EH, Paskhin ED, Prokunin AN, Rheol Acta, 15, 411 (1976).

13）高橋雅興, 小川健一郎, 升田利史郎, 日本レオロジー学会 誌， 18，180 (1990). 